\title{
Integration Conundrums: Framing and Responding to Climate Security Challenges in Development Cooperation
}

\author{
Veronica Brodén Gyberg ${ }^{1, * \mathbb{D}}$ and Malin Mobjörk ${ }^{2}$ \\ 1 Department of Thematic Studies, Tema Environmental Change, Linköping University, \\ 58183 Linköping, Sweden \\ 2 Stockholm International Peace Research Institute, 16972 Stockholm, Sweden; malin.mobjork@sipri.org \\ * Correspondence: veronica.broden.gyberg@liu.se; Tel.: +46-13-28-29-56
}

Citation: Gyberg, V.B.; Mobjörk, M. Integration Conundrums: Framing and Responding to Climate Security Challenges in Development Cooperation. Sustainability 2021, 13, 2582. https://doi.org/10.3390/ su13052582

Academic Editor:

Samuel Asumadu-Sarkodie

Received: 8 January 2021

Accepted: 22 February 2021

Published: 28 February 2021

Publisher's Note: MDPI stays neutral with regard to jurisdictional claims in published maps and institutional affiliations.

Copyright: () 2021 by the authors. Licensee MDPI, Basel, Switzerland. This article is an open access article distributed under the terms and conditions of the Creative Commons Attribution (CC BY) license (https:// creativecommons.org/licenses/by/ $4.0 /)$.

\begin{abstract}
This paper contributes to the burgeoning research on the integration of climate-related security risks by organizations. Development organizations have an important preventive mandate and can mitigate climate security challenges in low- and lower-middle-income economies, but they have a complex task, contending with power asymmetries and a very wide set of policy-making processes occurring in tandem. We explore how climate security challenges are being addressed in development organizations through focusing on the Swedish International Development Cooperation Agency (Sida), which has worked with integration of cross-sectoral issues since the 1980s. We narrow in specifically on how the overlaps between two separate policy areas at Sida—climate and conflicthave been framed and responded to in recent years. The study finds that the integration of these two areas is prioritized on a general policy level but that there are obstacles when translating policy into practice. Challenges include conceptual diversity, tensions between expert and general knowledge and differing organizational preconditions. Despite this, integration does occur between the two policy areas on several levels, ranging from a macro-level general awareness of potential overlaps with a "do no harm" ambition, to micro levels of integration in which strategies and interventions are adjusted.
\end{abstract}

Keywords: climate security; aid; development; integrated perspectives; climate change; environment; Swedish development cooperation

\section{Introduction}

If conflict is in the meeting title, a certain group of people show up. If there's environment and climate, another group of people come. If both environment and conflict is in the title, no humanitarian people show up. If you have resilience and risk, nobody comes, or maybe some humanitarian people. Conflict and climate are still kind of separate. Your background and terminology determine a lot.

Interview \#5, the Swedish International Development Cooperation Agency (Sida) Headquarters

The quote above is illustrative of some of the challenges that organizations face when attempting to integrate cross-sectoral issues such as gender, environment and conflict into all operations. A meeting title, for example, can enable or counteract cross-sectoral collaboration. This in turn is significant for how an organization, in this case Sida, can mitigate and address climate security challenges in the countries where it has development cooperation. In 2015, the Swedish Government updated its instruction to Sida [1] and called for an increased ambition to integrate the thematic issue areas-or perspectives-of environment and climate, conflict and gender. Although Sida had been tasked to integrate these areas earlier as well, the 2015 update added "conflict" and gave all perspectives equal weight, including the previously overarching rights-based perspective and perspectives of the poor. The key rationale behind policy pursuing integrated approaches is that measures 
undertaken in one (policy) area such as climate change may have implications for other policy areas. By taking into account the interconnectedness between different areas, maladaptation risks and other forms of unintended consequences may be reduced [2]. Previous studies show, however, that while high-level policies may underline the importance of integrating environment and climate with peace and security, the processes of translating policy into practice vary considerably [3]. Through their preventive mandate, aid actors are key in mitigating climate security challenges, yet little research has investigated how this is done, and with what effects.

This paper analyzes how Sida has developed its framings and responses related to climate security challenges since 2015. We focus specifically on the integration of the environment and climate perspective and the conflict perspective. Our analysis explores three dimensions of this:

1. How the connections between the policy areas "environment and climate" and "peace, conflict and security" are framed in central policies, in strategies and by Sida staff;

2. How Sida's organization and procedures respond to and support integration;

3. What challenges and opportunities arise when translating policy and strategy into practice.

The two perspectives are referred to as "environment and climate" and "conflict" in the instruction and high-level policies, but the conflict-related policy area at Sida is called "peace, conflict and security". This means that both forms will be used in this paper, depending on what is being referred to).

Our theoretical points of departure are based on the growing literature on climate security governance and insights from mainstreaming in official development assistance (ODA) from environmental policy integration (EPI) literature. We argue that this combination of scholarly fields is useful for examining the challenges faced by development organizations in framing and responding to climate security challenges. The analysis contributes to discussions on sustainable development and governance, not least discussions within environmental politics on mainstreaming and integration but also within development studies and climate security studies.

The study encompasses all geographical areas where Sida operates but narrows in specifically on work in Eastern Africa (specifically Ethiopia, Kenya, Somalia and Sudan). This region is chosen because Sweden is a significant donor in the region and often one of few to focus on the integration of thematic perspectives in all development programming. Probing into a specific region enabled the study of closer-to-the-ground experiences of challenges and opportunities with integrated approaches.

\subsection{Climate Security and Organizations' Responses}

Integrated approaches are considered vital for addressing and mitigating systemic and context-dependent security challenges posed by climate change [4,5]. A reason for this, according to Vivekananda et al. [6], is that climate change adaptation and mitigation interventions can inadvertently contribute to conflict or other forms of security challenges. Likewise, actions aimed at peace and conflict resolution may be hampered, fail or even worsen conflicts if they do not take the effects of environmental degradation and climate change into account. In other words, environment- and climate-related measures have to be conflict sensitive, and conflict prevention and peacebuilding have to be climate sensitive.

Despite the fact that integrated approaches have been found key for addressing cross-sectoral challenges [7], work in silos nevertheless tends to dominate. For instance, conceptual confusions, siloed organizations and funding streams have been identified as factors circumventing the ability to address climate security challenges [8]. Actions undertaken to manage these challenges occur in different areas, such as environment and climate change; adaptation and mitigation; natural resource management; peace, security and conflict; disaster risk reduction $[9,10]$. The responses are also spread across different units in organizations because climate change poses different types of risks and opportunities in different policy areas and geographical contexts. While not all development 
actors are explicitly tasked to work with climate security challenges, we argue development organizations are important actors in mitigating these challenges, particularly through their preventive mandate.

The research on climate security is diverse, but there is wide agreement that climate change impacts different dimensions of security including, but not limited to, human security [11]. One debated area has been when and under what circumstances climate change impacts violent conflicts. Despite disputes, experts agree that climate change does impact conflicts though it is not the primary factor behind why conflicts erupt [12]. An important research task, therefore, is to provide context-specific analysis on the mechanisms that translates climate change into security risks, including but not limited to violent conflicts, and also under which conditions it tends to do so $[13,14]$. Another aspect that has caused debate in the field is the "securitization" of the climate discourse; something which has been critiqued for being alarmist, short-term state-centric and border-oriented, for example [15-17]. Research also shows, however, that climate security has become increasingly linked to concepts such as complexity, preparedness, decentralization, empowerment and risk and resilience [18,19]. A fundamental transformative change is perceived as being necessary to protect humans and ecosystems. Matthew et al. argue that "environmental change reveals the connections - as well as the frictions-between the security of individuals and communities and the security and sustainability of ecosystems and species, including humanity" [20] (p. 4). Climate security discourse, therefore, includes both conventional and new forms of security understandings. Therefore, how climate security is understood and framed matters for how responses are tailored, by whom and for what.

Alongside the large, vivid debate on when and under what circumstances climate change impacts different forms of security, there is also growing scholarly interest in how organizations are framing and responding to these challenges. Although much of this debate has focused on how hard security actors' perceive climate change as a security risk, development actors are also paying attention to these challenges. In a review of research on global and regional organizations' responses to climate security challenges, Dellmuth et al. [21] found that there are mainly two strands of research, one situated in (critical) security studies, the other in governance studies. The first strand encompasses different forms of discourse analysis, exploring how organizations are framing climate change in security terms and critically scrutinizing the implications of that turn [22,23]. Important contributions have been made on securitization processes $[16,24]$ and on the different framings of security in the climate security debate $[25,26]$. Researchers have also investigated how climate security debates enter different organizations, such as the UN Security Council and the European Union [27-29].

The second strand of research emerges from governance studies, engaging with integrated governance $[4,30,31]$ and arguing that integrated approaches enable cross-cutting learning processes, joint understandings of concepts and improved expert knowledge across policy areas [32,33]. This research has also identified obstacles for integration such as diverging objectives and time frames [5]. Governance responses also appear to be influenced by how an organizations' mandate is interpreted [34,35].

A majority of the research on organizations' approaches to handling climate security challenges is situated in one of these strands; there are not many studies that examine both discourses and governance responses (exceptions include $[18,24,36]$ ). We argue that there are at least two good reasons for bridging these two analytical approaches. The first relates to the concept of security; multiple definitions and interpretations often exist within a single organization, hence what security means cannot be taken for granted and needs to be scrutinized. Secondly, the policy areas that are deemed relevant for addressing climate security challenges vary depending on the organization and their mandate. To enable improved governance responses, studies with a broader, more comprehensive perspective are also necessary. Hence, this study contributes to this growing body of research that bridges discourse oriented studies of how climate security is framed with governance oriented studies on organizations' responses, including preconditions for translating policy 
into practice. To advance the latter part, this paper uses concepts from EPI as an analytical entry point in order to investigate how Sida has developed its framings and responses related to climate security challenges since 2015 .

\subsection{Analytical Points of Departure}

The integration of environmental objectives into other sectors has been pursued based on an understanding that one sector alone cannot solve the problems identified. In the literature on environment or climate policy integration, the core objectives are the achievement of sustainable development, removing contradictions within and between policies, and the realization of mutual benefits $[37,38]$. An integrated policy is envisioned to recognize all significant consequences of the policy decision; policy options are evaluated on the basis of their effects, and different policy elements are in accord with each other [39]. There are clear overlaps between environment policy integration (EPI) and climate policy integration (CPI), the latter referring to similar processes but focusing specifically on climate change. In this paper, we use concepts from EPI, while also recognizing that climate can be more difficult to integrate or mainstream due to the cross-cutting nature of its causes and effects when compared to more geographically limited environmental problems [37].

In Lafferty and Hovden's definition of EPI, environmental objectives are conceived of as guiding and overarching principles in the non-environmental policy sector. They conceptualize EPI along horizontal and vertical dimensions; where the vertical EPI indicates to what extent a particular government sector has integrated environmental objectives, and the horizontal EPI indicates to what extent a central authority has developed cross-sectoral strategies addressing and balancing competing interests [39] (pp. 12-14). Persson and Klein [40], who build on Lafferty and Hovden, focused specifically on mainstreaming in official development assistance (ODA). Mainstreaming can be analyzed at different hierarchical administrative levels and can be classified as macro, meso and micro in character [41] (p. 416). The macro level refers to mainstreaming of general character (e.g., high-level policy); the meso level entails modifications of country strategies and sector programs; the micro level entails project design modifications (and more active seeking of synergies for example) on local levels.

The effects of mainstreaming can be investigated and analyzed in relation to policy inputs, process, outputs and outcomes [41]. This study applies these conceptualizations broadly and beyond the implementation of environmental objectives, extending it to the horizontal perspectives in focus in the study; environment and climate and conflict.

- In order to understand the policy inputs, it is of relevance to study the discourses-or explicitly expressed commitments relating to the issue/s in focus in for example high level policy. We analyze this mainly through policy documents but complemented with interviews.

- Understanding the process involves the study of procedural and organizational responses, which we analyze through both policy documents and the interviews.

- The policy outputs and outcomes refer to the ultimate impact on the ground, which we analyze though interviewees perspectives on challenges and opportunities with operationalization.

The concept of mainstreaming is sometimes used synonymously with integration, but in this paper, we understand integrated approaches as consisting of the deeper levels of mainstreaming, encompassing the meso and micro levels discussed above. Whether or not mainstreaming is successful - and by extension, whether an integrated approach is enabled-is the subject of debate and is highly context dependent. EPI in the specific context of foreign aid is characterized by special conditions when compared to domestic policy processes: there are two or more jurisdictions to contend with; there can be power asymmetries; tensions can arise when interventions aim to solve global problems not caused in the local context at hand; the policy making processes tend to be very wide, encompassing many strategic and operational decisions [41]. Mainstreaming success is also contingent on the amount of resources available for core issues versus the cross-cutting 
theme in question. There can be goal conflicts and trade-offs between policy areas, as well as difficulties with matching donor and recipient or partner country priorities. It also matters how mainstreaming is financed and organized; who decides what is mainstreamed, where and how [40].

\section{Materials and Methods}

The study is based on analysis of documents and interviews (see Appendix A for a list of materials). The documents included 14 general documents and high-level policies from the Government of Sweden and Sida, such as letters of appropriation and annual reports for the years 2015-2019 as well as current country and regional results strategies. The analysis also includes overarching strategies, national plans, thematic overviews and toolbox documents for the two policy areas in focus, i.e., environment and climate (27 documents) and peace, conflict and security (11 documents). Additional related but less central policy documents were also studied as a way to increase our background knowledge.

The document analysis was conducted in late 2018 and early 2019 and was guided by an abductive approach. A detailed initial reading enabled a general understanding of each document and its purpose and was followed by a more narrow and rigorous analysis guided by an operationalization of the research questions [42,43]. This analysis focused on; where and how environment and/or climate was discussed in the documents; where and how peace, conflict and security was mentioned; where and how these two areas were discussed together (which included how climate security is framed and discussed in connection to other specific policy areas, for example). While we did not formally include gender in the analysis, we acquired an understanding of its place in the policies in the process of analysis given that it was consistently present where environment and climate as well as conflict were discussed. While this does not necessarily allow for robust comparison, it does allow us to say something about how gender is mentioned in relation to the other two, which is of interest from a general mainstreaming perspective.

To deepen the analysis, 15 interviews were also conducted (some individual, others group: in total 24 people participated in spring 2019) with staff at Sida's headquarters (HQ) in Stockholm and at Swedish embassies operating in Ethiopia, Kenya, Somalia and Sudan. The interviewees were policy specialists, program officers, heads of department and heads of cooperation in embassies who worked with either environment and climate or peace, conflict and security (or both), or who had a responsibility for both areas at an embassy or a unit at Sida HQ.

The interviews were semi-structured in form, ran for about an hour each and were all built on the same set of questions [44]. The questions explored the informants' views on: the relationship between environment and climate and peace, conflict and security; how they worked with integrating each perspective in their area of work; what organizational structures and support existed to enable integrative work. Interviewees were also asked to provide examples of projects and programs that they considered as having integrated both perspectives in interesting ways and why.

The interviews were recorded and written summaries were produced for each one. The interview material was then analyzed with qualitative content analysis [45,46]. Driven by an abductive approach, as with the policy documents, switching between a deductive and an inductive logic [47]. The material was first organized according to each interview question with the purpose to create an overview and identify patterns as well as relevant examples to illustrate these. In a second step, the material was analyzed more inductively. This included a search for key words, which was both prompted by our understanding of the state of the art as well as based on the way the texts discussed the issues in focus. We searched for repetitions, omissions or unexpected statements (this way we could pick up on themes that we were not necessarily sensitized to) $[46,48]$. The interviews were coded for deidentification purposes, but references show whether the person was working at Sida HQ or at an embassy at the time. 
The analytical points of departure informed the way we performed the analysis in the sense that we conceptualized integrated approaches as the deeper levels of mainstreaming. The specific concepts were put to use more explicitly late in the process as a way to understand the levels of mainstreaming and integration at play in the complex and diverse operations involved and also in relation to the type of material studied. The EPI concepts helped structure the analysis.

\section{Results}

\subsection{Exploring the Policy Inputs: Multiple Framings and a Diversity of Concepts}

How are climate and conflict framed at Sida? This section focuses on the policy inputs, or explicitly expressed commitments, pertaining to climate and conflict at Sida. Our findings show that there are several concepts of relevance at use in parallel. Definitions vary and overlaps are not always explicitly addressed. Key concepts used at Sida include peace, conflict, security, human security, environment, climate, resilience, risk and "the triple nexus". The concept use depends on strategy and policy area in focus as well as organizational unit and staff expertise.

There is an increase in references to perspective integration in the government directives to Sida since 2015, but discussions about combined climate and conflict risks-or guidelines on how to implement integration-are generally absent. The different framings of concepts reflect how high-level policy documents are formulated; they address integration of all four perspectives in a general and macro-level manner. The high-level policies are overarching, but each policy area also has specific sets of policies and these refer to different extents to other policy areas and perspectives. For instance, documents on peace, conflict and security relate much more explicitly and consistently to the gender perspective than to environment and climate. Environment and climate are mainly mentioned indirectly and through references to sustainability and/or resilience. More specific references include statements such as "equitable distribution of resources" as one of the eight pillars of peace [49]. In environment and climate-specific documents, on the other hand, peace and security aspects, as well as gender, tend to be mentioned explicitly, albeit on a predominantly general level. Altogether, both policy areas consistently relate more to overlaps with gender equality as a policy area than they do to one another.

The country-specific results strategies from the Swedish MFA govern development cooperation efforts alongside global and regional strategies. Among the policy documents analyzed, these address the overlaps between the two perspectives most explicitly, albeit to varying degrees. The Ethiopia and Kenya strategies have environment and climate among their main goals; human rights and gender are also mentioned, but not conflict $[50,51]$. Conflict is, however, mentioned later in both strategies, in relation to natural resources, natural disasters and famine. The Somalia and Sudan strategies refer to "peaceful and inclusive societies", "sustainable peace" and "resilience, environment, climate change and energy" in their main goals and also discuss these issues together [52,53].

In the Sudan strategy, issues related to environment and climate change are explicitly identified as underlying causes of conflict [53] (pp. 4-5). The regional strategy for SubSaharan Africa relates to all the perspectives in its goals, including "better environment, sustainable use of natural resources, reduced climate impact and strengthened resilience to environmental impact, climate change and natural disasters" and "human security and freedom from violence" [54] (pp. 3-4). This strategy also discusses these issues in integrated ways:

Depleted natural resources and climate change, environmentally hazardous emissions and exposure to chemicals and waste puts a strain on ecosystems, on land and oceans, exacerbates livelihood opportunities and resilience, and risks creating tensions and conflicts.'

MFA Sub-Saharan Africa strategy 2016, p. 6 
The diversity of concepts and interpretations presents both challenges and opportunities. Internally, collaboration and integration across these policy areas is increasing, but the diversity reflects historic and current tensions, as exemplified by the quote in the introduction [55-58]. The diversity of concepts is not necessarily a problem, it can even be productive. In the Sida case, the diversity can be useful in collaboration with external partners that also employ a variety of concepts. The ability to adjust and be flexible regarding concepts can increase efficiency and strengthen the ownership of organizations in partner countries $[59,60]$. However, diversity can also create problems. The lack of clarity when it comes to concepts and their overlaps is something that is also a problem in the broader aid architecture, some staff argue. This can create unnecessary positioning instead of pursuing extended synergies [61].

One of the core concepts at Sida is the triple nexus, which is part of the UN "New Way of Working" [62]. The triple nexus calls for an increased collaboration between humanitarian aid, peace and development actors, which will enable common goals such as reducing risk and vulnerability (UN 2018). Some of the interviewees who work with peace, conflict and security consider that the triple nexus includes a resilience perspective and, therefore, encompasses environment and climate issues. Interviewees who mainly work with environment and climate, however, did not necessarily consider their area as being included in the triple nexus [57]. Altogether, this illustrates that central concepts are understood differently and coexist side by side. Furthermore, ideas about overlaps between policy areas differ as well.

According to several interviewees, "resilience" could be a unifying concept for Sida's work on integrating different perspectives and thereby also its work on climate-related security risks $[56,60,61]$. Some interviewees, however, maintained that resilience is mostly associated with environment and climate, but also to some extent with humanitarian aid:

Resilience has to be discussed; today it is mostly associated with environment and climate. Those who work with environment and climate should look more at disaster risk reduction and those who work with conflict should link peacebuilding to resilience.

\section{Interview \#5, Sida HQ}

In general though, resilience is less associated with peace, conflict and security, despite the fact that Sida considers peace, conflict and security to be an important part of resilience work. The Swedish word used to denote resilience at Sida is "motståndskraft", which in English is translated as "resistance". The Swedish translation clearly causes some confusion, and some informants consider it reflects the early stages of the resilience debate [56,61]. A 2019 report by the Swedish National Audit Office also points out that resilience is defined differently in different policy documents at Sida [63] (pp. 10,16). Another concept that is perceived by some Sida staff as a productive entry point is "risk". According to them, the risk concept enables a broader interpretation of resilience [56,64], which seems to be in line with what Ferguson labels "social resilience" in the climate security debate [19].

The interviewed staff, both at Sida HQ and at embassies, tended to describe climate change as a multiplier of negative effects related to environmental change and the management of natural resources. The connections between climate change and security challenges were portrayed as being quite clear to the staff working with Eastern Africa, some of whom also worked with the Sahel region. Water resource management was perceived as one of the biggest current challenges and a clear example of how climate and security can relate to one another. Food security and climate change adaptation capacity more broadly were also mentioned as key challenges $[56,57,65,66]$. Embassy staff tended to focus more on institutional architecture and practical opportunities and challenges rather than concepts and definitions. Resilience was mentioned, however, as well as the New Way of Working and the triple nexus. These were both considered broad and useful points of departure for working with all the perspectives in conjunction with the increased coordination between humanitarian aid and development cooperation. This in turn was seen to improve preconditions to work with climate security challenges $[66,67]$. 
In a study focusing on Sida's counterpart in the UK, the Department for International Development, Boas and Rothe conclude that while climate-resilience storylines can be "diverse and messy", the concept has been productive through its flexibility: many different actors are able to relate to it. They maintain that resilience acknowledges complexity and uncertainty and disconnects from alarmist tones, turning the prevention of climate-related conflict into a broader societal endeavor that enables a more bottom-up approach [18]. Old climate conflict storylines have not been replaced but rather merged with new ones and rearticulated in light of resilience discourse. Whether or not this is indicative of a bottomup process is debated [68,69], but the situation seems similar at Sida in the sense that old concepts are being rearticulated in light of new ones. Diversity still prevails in terms of what concepts are considered central for understanding the climate-conflict overlap.

The lack of consistent and explicit engagement on the overlapping aspects of different policy areas can hamper both climate and conflict efforts [6], and our analysis indicates that there is potential for more interaction between climate and conflict in terms of policy input in order to achieve meso- and micro-level integration more consistently. The relationships between the different thematic areas, overlaps as well as potential goal conflicts and trade-offs could be more explicitly and consistently discussed in high-level policies.

\subsection{Organizational Preconditions and Processes: Enabling (Dis)Integration?}

As illustrated by the discussion above, the way concepts are interpreted is partly dependent on how individuals relate these concepts to already established routines. In order to understand how specific concepts are framed in an organization, it is necessary to consider the institutional architecture in question and how work is undertaken in the organization. Using the EPI terminology, the focus is here on process.

Sida has engaged explicitly in the overlap between the two policy areas in several ways [70-72]. Furthermore, mainstreaming and integration is not a new phenomenon at Sida. The agency has worked with peace, conflict and security, as well as environment and climate, for decades, even though different concepts have been in focus. The environment was included in Sida's central goals in 1988. Peace, conflict and security has been a policy area since 1999 but joined as a thematic perspective in 2015 and more central resources were made available to the area [73]. Mainstreaming ambitions at Sida have generally been difficult to implement fully and evenly. The same goes for gender, which has the longest history of mainstreaming at Sida. Competition between policies and perspectives, lack of adequate management, monitoring and follow-up, varying knowledge and competence about each policy area as well as varying levels of engagement/interest have been identified as obstacles to mainstreaming $[7,74,75]$. When there are "too many" perspectives or issues to integrate, "mainstreaming fatigue" can also occur. This was emphasized in the Organization for Economic Co-operation and Development (OECD) Development Assistance Committee (DAC) evaluation of Sida in 2019 in connection to their discussion on the number of strategies at Sida and the lack of links between them [76]:

While strategies individually are aligned to the policy framework, there are not clear connections among them and this can result in duplication of funding to partners and lost opportunities to create synergies.

OECD Development Cooperation Peer Reviews: Sweden 2019, p. 37

When it comes to addressing combined climate and conflict challenges, Sida does not have a unit or other institutional entity to gauge the work. Instead, the approach is that all policy areas and corresponding units have to integrate all perspectives into all its operations. For each perspective, Sida has appointed a lead policy specialist to coordinate the work; the lead policy specialist for peace and security was established after the 2015 decision, while the policy specialist for environment and climate has existed for longer [75]. The main task of the lead policy specialists is to create good preconditions for the integration of their perspectives. This happens through supporting Sida's internal work through networks and by developing working guidelines (e.g., toolbox documents), representing the agency externally, and supporting Sida's General Director, the MFA and the Government. A key 
challenge is to determine which work should be done on what level in order to achieve sufficient breadth and specialization. Some aspects of the perspective integration are, for example, relevant to discuss while preparing for new country strategies, others are best discussed when preparing concrete initiatives [61]. There are also expert advisors employed at different departments and units at Sida as well as at Swedish embassies. The expert advisors collaborate with the lead policy specialists within each perspective and with each other, but to varying degrees $[58,77]$. In some units and departments, staff have an explicit task to work with the integration of more than one perspective; in others, they are tasked to focus on resilience more broadly $[56,57,76]$. Sida has also begun recruiting embassy staff with an explicit task to bridge humanitarian aid and development cooperation with the resilience programs. This is, for instance, the case in the Sahel and the Horn of Africa.

The 2015 decision appears to have improved the preconditions for integrated work and collaboration between the policy areas environment and climate and peace, conflict and security. Achieving both breadth and depth consistently, however, is considered difficult. Time for systematic and long-term integration work is perceived as lacking, and several interviewees maintained that the administrative allocation is too small in relation to the extensive operations being managed $[55,57,59,65,78]$. A similar conclusion was drawn in the 2019 OECD DAC evaluation referred to earlier, which stated that Sida is understaffed in relation to its growing ODA budget, not least in relation to the area of environment and climate change. It is relevant to mention here that Sida's administrative allocation was been increased significantly in 2020.

Lack of knowledge has been identified as a key obstacle for integrative work in previous studies [3]. Some Sida interviewees expressed that there is a deep-seated tradition of expertise that values in-depth knowledge about specific perspectives or associated subareas. This is perceived as something that hampers the ability to bridge different areas of expertise and thereby also integration $[59,66]$. The interviewees generally maintained that in-depth expertise is important, but that sufficient knowledge about all perspectives is necessary in order to be able to see the connections among them. There are a number of horizontally oriented processes that the interviewees considered conducive to integrated approaches-such as working in teams, conducting OECD resilience assessments, working with Agenda 2030 and implementing Sida's own environmental plan and conducting a multidimensional poverty analysis (MDPA). The MDPA was mentioned the most and was described as a useful starting point for improving knowledge and understanding across policy areas $[56,58,60]$. Despite some critique, they felt that the MDPA has good potential, because it includes all the perspectives and looks at several dimensions and contexts in order to better understand who is poor, how and why, as exemplified below:

When people are poor in multiple dimensions, there is an increased likelihood that they will not have, or have access to, the resources and opportunities needed to manage risks and maintain their well-being when exposed to shocks. Furthermore, different risks may have a more or less severe impact on people living in poverty. For example, people living in poverty can be exposed to floods and droughts. When a flood hits, they might lose their belongings or have to make choices with detrimental long-term effects, such as withdrawing children from school, cutting down trees, selling off cattle or reducing health care expenditures.

Dimensions of Poverty. Sida's Conceptual Framework (2017), Sida, p. 15

The demands on knowledge, however, are perceived to have increased and time for competence development is lacking [65]. Sida has external knowledge resources for all perspectives - helpdesks - but a tension exists regarding in-house knowledge versus external expertise. Additionally, the knowledge that the helpdesks assist with does not generally include integration with the other perspectives; instead, contextualization and practical application is up to Sida [60].

Sida's decentralized model of development cooperation entails that embassies are relatively autonomous; they might, for example, demand quite different kinds of support from Sida HQ depending on the current management, strategies in focus and staff profiles. 
Experience exchange and dialogue are perceived to be more prevalent in the work with preparing strategies, but less so in operationalization phases. One way for Sida HQ to complement and support the operationalization is to "boost" embassies with a temporary competence team on a certain theme; this is something that has been tested only recently. This also means that Sida HQ has varying ability to steer and support the integration of perspectives on country levels, which is the level where policy also becomes translated into practice.

In all, the analysis shows that organizational preconditions and responses are mixed and only partially geared towards integrated work.

\subsection{Translating Policy into Practice: A Glimpse into the Challenges and Opportunities of Implementation}

High-level policies in development organizations sometimes include phrases underlining the importance of integration of environment and climate with peace, conflict and security. The translation of policy into practice on the ground, however, varies considerably, and the quest for coordination and synergies is difficult [3]. A key challenge for aid actors is to bring together the management of issue areas that tend to remain divided. While this study mainly focuses on the policy inputs and processes, policy outputs and outcomes are also addressed here through discussing some of the challenges and opportunities that arise when translating Sida's polices and strategies into practice in Eastern Africa.

The interviewed Sida staff working with Ethiopia, Kenya, Somalia and Sudan (both those based at Sida HQ and those based at embassies) considered the results strategies (discussed in Section 3.1) as adequate points of departure for their work, although it is sometimes for example considered difficult to determine whether the strategy goals or the perspectives weigh the heaviest. At the same time, flexibility is seen as important and necessary, not least when operating in contexts with recurring humanitarian crises and conflict [64]. This is also emphasized in the evaluations by the OECD 2019 as well as Guljarani and Mills [79]. Sida staff express that when there is alignment between goals and perspectives in strategies and other instructions, the preconditions for integrated work become stronger $[58,59,64]$. If strategies do not encompass all four perspectives, synergy opportunities are missed. One reason for this is that recruitment may then not cover all competences required for the integrated work $[58,66]$. Some Sida HQ staff stated that an increase in the level of context-specific information in country strategies might facilitate perspective integration. Related to this, the importance of high-quality local, national and regional context analyses (both short- and long-term) was raised, both in relation to strategy development and for efficient implementation [55,61,64].

One of the biggest challenges for Sida staff working in fragile contexts is that they often have to focus on short-term needs. This reduces the ability to simultaneously address the long-term goals that are necessary to handle many climate-related challenges, such as those related to agriculture [53,77] (p. 8). Another challenge can be the lack of local partners to work with and, consequently, lack of continuity. To counteract this, collaboration with larger multilateral actors becomes essential, as they have a presence in the countries and access to various areas and actors [77]. This also implies, however, that Sida's priorities need to be aligned with those of the collaborating actors. If these actors do not align with Sida priorities, it might be difficult to work with the perspectives. Similarly, national priorities in the partner country can also differ from the aid actors'; environment and climate may not be high on the political agenda in the partner country. At the same time, some experiences suggest that environment and climate can be a less politically sensitive entry point to work with compared to conflict, illustrating the importance of flexible and context-specific strategies [60,77].

The increased focus on coordination between humanitarian aid and development cooperation was perceived by staff as important for being able to work with the overlap between environment and climate and peace, conflict and security. Better internal incentives for integration and common goals were called for by one interviewee, who also pointed out that different policy areas measure progress differently [67]. Explicitly recruiting 
competences that bridge humanitarian aid and development cooperation is something that staff considered positive for the integration of climate and conflict. Nevertheless, humanitarian aid remains necessarily focused on the short term, while development cooperation has to have a longer perspective; the challenges remain [80]. The following quote illustrates the kind of tensions that exist:

Everybody is talking about preventing crises and working with links between humanitarian aid and development-and this depends on which donors-but a lot of it has to do with migration as a problem, especially in the EU-context. Those who were our like-minded before are not anymore. Things have changed Interview \#12, Embassy

The quote indicates that donor countries have different views now compared to before when it comes to the reasons why humanitarian and development aid need to be better coordinated. This statement also reflects conclusions made in previous studies; the attention to climate-related security risks is simultaneously based on a more traditional threat and conflict concerns, as well as the broader orientation towards borderless (human) development and resilience [18]. Both perspectives can inform commitments to climaterelated aid, for example, or as in the case with the quote above, increased attention to the overlap between humanitarian aid and development cooperation. Sida's German counterpart, Deutsche Gesellshaft für Internationale Zusammenarbeit $\mathrm{GmbH}$, also indicates that the link between climate change and migration has further spurred the interest in working in a more integrated way with these issues (e.g., within the New Way of Working), but that it is difficult to work preventive long-term approaches in fragile contexts [9].

The challenges that staff experience when translating policy into practice are reflective of the special conditions faced by foreign aid operations when compared to for example domestic policy processes, as discussed earlier [41]. Policy-making processes in this kind of context encompass a wider range of strategic and operational decisions. Though high-level policy may provide reasonable preconditions for integrated work, the general challenges with mainstreaming in addition to the need for short-term flexibility can crowd out efforts to prioritize long-term action towards integration.

\section{Concluding Discussion: Integration Conundrums in Swedish Development Cooperation}

Focusing on how Sida has developed its framings and responses related to climate security challenges, this paper has analyzed how the connections between climate and conflict are framed in central policies, in strategies and by Sida staff. It has also explored how Sida's organization and procedures support integrated work and specifically probed into challenges and opportunities that arise when translating policy and strategy into practice. Thereby, it contributes to the emerging literature exploring how different kinds of organizations are developing it responses to climate security challenges [18,21,24].

This study has shown that the government's directive to Sida, which emphasized increased integration, has created improved preconditions for integrated work. Many initiatives aimed at integrating the two perspectives of environment and climate and conflict are being undertaken at Sida. Sida's capacity to address climate security challenges has been strengthened, but work is still partly done in silos. Discussions about combined climate and conflict risks are generally absent and so are guidelines on how to implement integration. Environment and climate documents slightly more often raise peace, conflict and security than the other way around, and both areas refer more consistently to gender than to one another. The overlaps between the two perspectives and policy areas are most clearly highlighted in the country results strategies.

The policy inputs, i.e., the discourses and the explicitly expressed commitments, are not consistently aligned. There is a diversity of concepts used pertaining to the overlap between the perspectives, both in policy and in practice. The understanding and use of central concepts vary depending on background, policy area and unit. This diversity reflects the complexity of the topic in focus. It is evident that the multiple framings cause uncertainties, but there are also advantages. The diversity can enable collaboration and 
cohesion internally, but the lack of clarity also risks upholding and creating boundaries between environment and climate and peace, conflict and security. The diversity also enables some flexibility in collaboration with external partners, as it enables Sida to adjust its framing to the specific context. However, this process could benefit from an increased internal clarity of concepts, their overlap and interrelation. Otherwise, Sida risks reducing its ability to fulfil the priorities and goals decided by the government.

In terms of the process, organizational preconditions are mixed. The support for integrated work is fragmented; there are tensions between expertise and general knowledge. The approaches to, and implementation of, an integrated approach seem to differ within Sida depending on policy area (environment and climate or peace, conflict and security), level (globally, regionally or bilaterally) and unit (different divisions at Sida and different geographic areas). The resources available for integrated work are limited. The present analysis adds to the findings of previous studies, pointing towards the need to strengthen the expertise internally with regard to cross-cutting issues. As Sida uses help desks to support its work on specific issue areas, it could be relevant to revisit the instructions to them, thereby increasing their potential of enabling integration.

Reflecting the conceptual diversity and mixed organizational preconditions, staff at Sida HQ and embassies indicated that there are different levels of integration of, and between, the two policy areas. These range from a macro-level general awareness of the potential overlaps with a "do no harm" ambition to micro levels of integration where strategies and interventions are adjusted, and synergies are actively sought. Sida's decentralized model of development is considered simultaneously, being a challenge and an important success factor. While the translation of policy into practice occurs on several levels at Sida, there seems to be room for increased collaboration on operationalization, particularly between Sida HQ and embassies as well as between Sida and collaborating partners. This could enable deeper levels of integration. Interviewed staff also considered the coordination between humanitarian aid and development cooperation as key for working with the overlap between environment and climate and peace, conflict and security. At the same time, working with long-term processes can be a significant challenge in fragile contexts due to the pressing short-term needs.

In some contexts, Sida is one of few aid actors working with environment and climate and emphasizing an integrated approach. Sweden's role as a capacity-building partner in these contexts could be strengthened and complement other aid actors more strategically. Moreover, Sida's focus is on the most fragile states, which in general receive a low proportion of climate-related aid. Therefore, Sida's focus on fragile contexts provides an important foundation for strengthening adaptive capacity and mitigating climate security challenges. As such, it also enables contribution to the implementation of the 2030 Agenda and addresses the double burden of climate change and fragility. An important principle for Sida's as well as other aid actors' forthcoming efforts is to go beyond the do-no-harm approach and prioritize measures that do not occur at the expense of long-term sustainable management of natural resources. To enable this, and to improve capacities to address climate-related security challenges, additional efforts are required to ensure that relevant policy areas and actors are developing climate-proof and conflict-sensitive approaches.

Finally, it is a matter of debate whether current forms of organizing aid are adequate for horizontal issues and objectives. Some researchers argue that bold reforms of the international institutional aid architecture and political action are required, especially considering the challenges faced in increasingly fragile contexts [81-83]. Our analysis of framings and responses at Sida shows that integration of, but not least between, climate and conflict is considered important but difficult in practice. There is potential for additional synergies. Using EPI language, the horizontal integration is partial, and strategies to balance cross-sectoral competing interests are not consistently present. While integration is occurring on macro, meso and micro levels, the integration is not consistent, and strong incentives for maintaining vertical silos remain. This paper has pointed out key 
challenges and opportunities, which could inspire further research on how these dilemmas are best solved.

Author Contributions: Conceptualization, V.B.G. and M.M.; methodology, V.B.G.; formal analysis, V.B.G. and M.M.; investigation, V.B.G.; writing—original draft preparation, V.B.G.; writing—review and editing, V.B.G. and M.M.; project administration, M.M.; funding acquisition, M.M. All authors have read and agreed to the published version of the manuscript.

Funding: This work was supported by funding from the Swedish Ministry for Foreign Affairs as part of the Strategic grant to Stockholm International Peace Research Institute, SIPRI, and the Swedish Foundation for Strategic Environmental Research Mistra Geopolitics program.

Institutional Review Board Statement: Not applicable.

Informed Consent Statement: Informed consent was obtained from all subjects involved in the study.

Data Availability Statement: The documents studied are publicly available. The interviews were conducted with the guarantee that they would remain deidentified.

Acknowledgments: We are grateful for draft comments by participants in the session on Environmental Politics at the SWEPSA annual meeting 2019.

Conflicts of Interest: The funders had no role in the design of the study; in the collection, analyses, or interpretation of data; in the writing of the manuscript, or in the decision to publish the results.

\section{Appendix A List of Empirical Materials}

Table A1. Interviews.

\begin{tabular}{cc}
\hline Interview \#1, Sida HQ Sthlm, Dec 2018 \\
\hline Interview \#2, Sida HQ Sthlm, Jan 2019 \\
\hline Interview \#3, Sida HQ Sthlm, Jan 2019 \\
\hline Interview \#4, Sida HQ Sthlm, Jan 2019 \\
\hline Interview \#5, Sida HQ Sthlm, Jan 2019 \\
\hline Interview\#6, Sida HQ Sthlm, Jan 2019 \\
\hline Interview \#7, Sida HQ Sthlm, Jan 2019 \\
\hline Interview \#8, Sida HQ Sthlm, Feb 2019 \\
\hline Interview \#9, Sida HQ Sthlm, Feb 2019 \\
\hline Interview \#10, Sida HQ Sthlm, Feb 2019 \\
\hline Interview \#11, Embassy, March 2019 \\
\hline Interview \#12, Embassy, April 2019 \\
\hline Interview \#13, Embassy, April 2019 \\
\hline Interview \#14, Embassy, April 2019 \\
\hline Interview \#15, Embassy, April 2019 \\
\hline
\end{tabular}

Table A2. Documents.

\begin{tabular}{cc}
\hline Year & Document Name \\
\hline 2014 & Resultatstrategi för globala insatser för socialt hållbar utveckling 2014-2017 \\
\hline 2015 & Instruktion för Styrelsen för internationellt utvecklingssamarbete \\
\hline 2015 & Regleringsbrev för budgetåret 2015 avseende Styrelsen för internationellt \\
& utvecklingssamarbete \\
\hline 2016 & Årsredovisning 2015 \\
\hline
\end{tabular}


Table A2. Cont.

\begin{tabular}{|c|c|}
\hline Year & Document Name \\
\hline 2016 & $\begin{array}{l}\text { Regleringsbrev för budgetåret } 2016 \text { avseende Styrelsen för internationellt } \\
\text { utvecklingssamarbete }\end{array}$ \\
\hline 2017 & Årsredovisning 2016 \\
\hline 2017 & $\begin{array}{l}\text { Regleringsbrev för budgetåret } 2017 \text { avseende Styrelsen för internationellt } \\
\text { utvecklingssamarbete }\end{array}$ \\
\hline 2018 & Årsredovisning 2017 \\
\hline 2018 & $\begin{array}{l}\text { Regleringsbrev för budgetåret } 2018 \text { avseende Styrelsen för internationellt } \\
\text { utvecklingssamarbete }\end{array}$ \\
\hline 2019 & Årsredovisning 2018 \\
\hline 2017 & $\begin{array}{c}\begin{array}{l}\text { Riktlinjer för strategier inom svenskt utvecklingssamarbete och humanitärt } \\
\text { bistånd }\end{array} \\
\end{array}$ \\
\hline 2017 & Strategy for Multilateral development policy \\
\hline 2018 & $\begin{array}{c}\text { Regleringsbrev för budgetåret } 2018 \text { avseende Styrelsen för internationellt } \\
\text { utvecklingssamarbete }\end{array}$ \\
\hline 2018 & $\begin{array}{l}\text { Strategi för kapacitetsutveckling, } \\
\text { partnerskap och metoder som stöder Agenda } 2030 \text { för hållbar utveckling }\end{array}$ \\
\hline 2018 & $\begin{array}{l}\text { Strategy for Sweden's development cooperation in the areas of human rights, } \\
\text { democracy and the rule of law 2018-2022 }\end{array}$ \\
\hline 2015 & Gender, Peace and Security \\
\hline 2016 & $\begin{array}{c}\text { Peace and Security. Preventing conflict, sustaining peace and promoting human } \\
\text { security }\end{array}$ \\
\hline 2016 & $\begin{array}{c}\text { Stockholm Declaration. Addressing Fragility and Building Peace in a Changing } \\
\text { World }\end{array}$ \\
\hline 2016 & $\begin{array}{l}\text { Women, Peace \& Security. Sweden's National Action Plan for the implementation } \\
\text { of the UN Security Council's Resolutions on Women, Peace and Security 2016-2020 }\end{array}$ \\
\hline 2017 & Strategy for Sustainable Peace 2017-2022 \\
\hline 2017 & $\begin{array}{l}\text { Conflict Prevention: Opportunities and challenges in implementing key policy } \\
\text { commitments and priorities }\end{array}$ \\
\hline 2017 & Preventing Violent Extremism (PVE) through development \\
\hline 2017 & Defining Key Concepts, Tools and Operational Responses \\
\hline 2017 & Building and assessing institutional capacity to integrate conflict sensitivity \\
\hline 2017 & Conflict sensitivity in programme management \\
\hline 2017 & Sida's approach to an integrated conflict perspective \\
\hline 2015 & $\begin{array}{c}\text { Environment and Climate Change. A sustainable development within planetary } \\
\text { boundaries }\end{array}$ \\
\hline 2016 & Genomförandeplan för Sidas arbete med miljömål 2016-2019 \\
\hline 2016 & Introduction to Environment and Climate Change Integration in Contributions \\
\hline 2016 & Guidelines for Sida's Screening prior to an Environmental Assessment \\
\hline 2016 & Guidelines for a Simplified Environmental Assessment \\
\hline 2016 & Guidelines to Appraise a Simplified Environmental Assessment \\
\hline 2016 & Pesticides in Agriculture \\
\hline 2016 & Urban Development, Biodiversity and Ecosystems \\
\hline 2016 & $\begin{array}{l}\text { Organisation strategy for Sweden's cooperation with the Green Climate Fund for } \\
\qquad 2016-2018\end{array}$ \\
\hline 2016 & $\begin{array}{l}\text { Organisation strategy for Sweden's cooperation with the Global Environmental } \\
\text { Facility (GEF) 2016-2018 }\end{array}$ \\
\hline
\end{tabular}


Table A2. Cont.

\begin{tabular}{|c|c|}
\hline Year & Document Name \\
\hline 2016 & Introduction to Environment and Climate Change Integration in Contributions \\
\hline 2016 & Climate Change. Increasing support for climate action \\
\hline 2016 & Agenda 2030 and Ecosystems \\
\hline 2017 & $\begin{array}{l}\text { A guide to support implementation of the Paris agreement, part 1: Supporting } \\
\text { Access to Finance for Climate Action }\end{array}$ \\
\hline 2017 & $\begin{array}{l}\text { A guide to support implementation of the Paris agreement, part 2: Towards Green } \\
\text { Climate Fund Accreditation and Support }\end{array}$ \\
\hline 2017 & $\begin{array}{l}\text { A guide to support implementation of the Paris agreement, part 3: Integrating } \\
\text { Climate Action into National Development Planning-Coherent Implementation of } \\
\text { the Paris Agreement and Agenda } 2030\end{array}$ \\
\hline 2017 & Human Rights, Biodiversity and Ecosystems \\
\hline 2017 & Sida's Environment policy \\
\hline 2017 & Chemicals and Hazardous Waste \\
\hline 2017 & Climate Smart Agriculture \\
\hline 2017 & Green Economy-Why, What and How? \\
\hline 2017 & $\begin{array}{c}\text { Dialogue Support for a Green Economy-Environment Integration in Employment, } \\
\text { Market Development and Trade }\end{array}$ \\
\hline 2017 & Environmental targets 2017-2020 \\
\hline 2018 & $\begin{array}{c}\text { Strategy for Sweden's global development cooperation in the areas of } \\
\text { environmental sustainability, sustainable climate and oceans, and sustainable use } \\
\text { of natural resources } 2018-2022\end{array}$ \\
\hline 2017 & The relationship between climate change and violent conflict \\
\hline 2016 & $\begin{array}{l}\text { Regional Strategy for Sweden's Development Cooperation with the Middle East } \\
\text { and North Africa (MENA) 2016-2010 }\end{array}$ \\
\hline 2016 & $\begin{array}{l}\text { Strategy for Sweden's regional development cooperation in Sub-Saharan Africa } \\
\qquad 2016-2021\end{array}$ \\
\hline 2016 & Strategy for Sweden's development cooperation with Ethiopia 2016-2020 \\
\hline 2016 & Strategy for Sweden's development cooperation with Kenya 2016-2020 \\
\hline 2018 & Strategy for Sweden's development cooperation with Somalia 2018-2022 \\
\hline 2018 & Strategy for Sweden's development cooperation with South Sudan 2018-2022 \\
\hline 2018 & Strategy for Sweden's development cooperation with Sudan 2018-2022 \\
\hline
\end{tabular}

\section{References}

1. Government Offices of Sweden. Directive (2010:1080) with Instructions for the Swedish International Development Cooperation Agency (Sida), Addition Concerning Perspectives SFS 2015:378; Government Offices of Sweden: Stockholm, Sweden, 2010.

2. Magnan, A.K.; Schipper, E.L.F.; Burkett, M.; Bharwani, S.; Burton, I.; Eriksen, S.; Gemenne, F.; Schaar, J.; Ziervogel, G. Addressing the risk of maladaptation to climate change. WIREs Clim. Chang. 2016, 7, 646-665. [CrossRef]

3. Gustafsson, M.T. How do Development Organisations Integrate Climate and Conflict Risks? Experiences and Lessons Learnt from the UK, Germany and The Netherlands; Stockholm University: Stockholm, Sweden, 2016.

4. Birkmann, J.; Teichman, K. Integrating disaster risk reduction and climate change adaptation: Key challenges-Scales, knowledge, and norms. Sustain. Sci. 2010, 5, 171-184. [CrossRef]

5. Matthew, R. Integrating climate change into peacebuilding. Clim. Chang. 2014, 123, 83-93. [CrossRef]

6. Vivekananda, J.; Schilling, J. Climate resilience in fragile and conflict-affected societies: Concepts and approaches. Dev. Pract. 2014, 24, 487-501. [CrossRef]

7. Uggla, F. Mainstreaming at Sida: A Synthesis Report; Swedish International Development Cooperation Authority (Sida): Stockholm, Sweden, 2007.

8. Mobjörk, M.; Gustafsson, M.; Sonnsjö, H.; van Baalen, S.; Dellmuth, L.M.; Bremberg, N. Climate-Related Security Risks: Towards an Integrated Approach; SIPRI and Stockholm University: Solna, Sweden, 2016. 
9. Harjanne, A.; Haavisto, R.; Tuomenvirta, H.; Gregow, H. Risk management perspective for climate service development-results from a study on Finnish organizations. Adv. Sci. Res. 2017, 14, 293-304. [CrossRef]

10. Mercer, J.; Kelman, I.; do Rosario, F.; de Deus de Jesus Lima, A.; da Silva, A.; Beloff, A.M.; McClean, A. Nation-building policies in Timor-Leste: Disaster risk reduction, including climate change adaptation. Disasters 2014, 38, 690-718. [CrossRef]

11. Gemenne, F.; Barnett, J.; Adger, W.N.; Dabelko, G.D. Climate and security: Evidence, emerging risks, and a new agenda. Clim. Chang. 2014, 123, 1-9. [CrossRef]

12. Mach, K.J.; Kraan, C.M.; Adger, W.N.; Buhaug, H.; Burke, M.; Fearon, J.D.; Field, C.B.; Hendrix, C.S.; Maystadt, J.-F.; O’Loughlin, J.; et al. Climate as a risk factor for armed conflict. Nature 2019, 571, 193-197. [CrossRef] [PubMed]

13. Buhaug, H. Climate-Conflict Research: Some Reflections on the Way Forward. WIREs Clim. Chang. 2015, 6, 269-275. [CrossRef]

14. Van Baalen, S.; Mobjörk, M. Climate change and violent conflict in East Africa: Integrating qualitative and quantitative research to probe the mechanisms. Int. Stud. Rev. 2018, 20, 547-575. [CrossRef]

15. Corry, O. Securitisation and 'Riskification': Second-order Security and the Politics of Climate Change. Millenium J. Int. Stud. 2012, 40, 235-258. [CrossRef]

16. Trombetta, M. Linking climate-induced migration and security within the EU: Insights from the securitization debate. Crit. Stud. Secur. 2014, 2, 131-147. [CrossRef]

17. Warner, J.; Boas, I. Securitization of climate change: How invoking global dangers for instrumental ends can backfire. Environ. Plan. C Politics Space 2019, 37, 8. [CrossRef]

18. Boas, I.; Rothe, D. From conflict to resilience? Explaining recent changes in climate security discourse and practice. Environ. Politics 2016, 25, 613-632. [CrossRef]

19. Ferguson, P. Discourses of Resilience in the Climate Security Debate. Glob. Environ. Politics 2019, 19, 104-126. [CrossRef]

20. Matthew, R.A.; Barnett, J.; McDonald, B.; O’Brien, K.L. Global Environmental Change and Human Security; MIT Press: Cambridge, MA, USA, 2010.

21. Dellmuth, L.; Gustafsson, M.; Bremberg, N.; Mobjörk, M. Intergovernmental organizations and climate security: Advancing the research agenda. WIREs Clim. Chang. 2018, 9, e496. [CrossRef]

22. Baldwin, A.; Methmann, C.; Rothe, D. Securitizing 'climate refugees': The futurology of climate-induced migration. Crit. Stud. Secur. 2014, 2, 121-130. [CrossRef]

23. Hartmann, B. Rethinking climate refugees and climate conflict: Rhetoric, reality and the politics of policy discourse. J. Int. Dev. 2010, 22, 233-246. [CrossRef]

24. Oels, A. Rendering climate change governable by risk: From probability to contingency. Geoforum 2013, 45, 17-29. [CrossRef]

25. Detraz, N.; Bestill, M. Climate Change and Environmental Security: For Whom the Discourse Shifts. Int. Stud. Perspect. 2009, 10, 303-320. [CrossRef]

26. McDonald, M. Climate change and security: Towards ecological security? Int. Theory 2018, 10, 153-180. [CrossRef]

27. Floyd, R. Global climate security governance: A case of institutional and ideational fragmentation. Confl. Secur. Dev. 2015, 15, 119-146. [CrossRef]

28. Youngs, R. Climate Change and European Security; Routledge: New York, NY, USA, 2015.

29. Zwolski, K.; Kaunert, C. The EU and climate security: A case of successful norm entrepreneurship? Eur. Secur. 2011, 20, 21. [CrossRef]

30. Kelman, I. Climate change and the Sendai framework for disaster risk reduction. Int. J. Disaster Risk Sci. 2015, 6, 117-127. [CrossRef]

31. Schipper, L.; Pelling, M. Disaster risk, climate change and international development: Scope for, and challenges to, integration. Disasters 2006, 30, 19-38. [CrossRef] [PubMed]

32. Schipper, E.L.F.; Thomalla, F.; Vulturius, G.; Davis, M.; Johnson, K. Linking disaster risk reduction, climate change and development. Int. J. Disaster Resil. Built Environ. 2016, 7, 216-228. [CrossRef]

33. McBean, G.A. Coping with global environmental change: Need for an interdisciplinary and integrated approach. In Coping with Global Environmental Change, Disasters and Security; Springer: Berlin, Germany, 2011; pp. 1193-1204.

34. Bremberg, N.; Sonnsjö, H.; Mobjörk, M. The EU and Climate Security: A community of practice in the making? J. Eur. Integr. 2018, 41, 623-639. [CrossRef]

35. Conca, K.; Thwaites, J.; Lee, G. Climate change and the UN Security Council: Bully pulpit or bull in a china shop? Glob. Environ. Politics 2017, 17, 1-20. [CrossRef]

36. Depledge, D.; Feakin, T. Climate change and international institutions: Implications for security. Clim. Policy 2012, 12, 73-84. [CrossRef]

37. Rietig, K. The importance of compatible beliefs for effective climate policy integration. Environ. Politics 2019, 28, 228-247. [CrossRef]

38. Collier, U. Sustainability, subsidiarity and deregulation: New directions in EU environmental policy. Environ. Pol. 1997, 62, 1-23. [CrossRef]

39. Lafferty, W.; Hovden, E. Environmental policy integration: Towards an analytical framework. Environ. Politics 2003, 12, 1-22. [CrossRef]

40. Persson, A.; Klein, R.T. Mainstreaming Adaptation to Climate Change into Official Development Assistance: Integration of Long-Term Climate Concerns and Short-Term Development Needs; Stockholm Environment Institute: Stockholm, Sweden, 2008. 
41. Persson, Å. Environmental policy integration and bilateral development assistance: Challenges and opportunities with an evolving governance framework. Int. Environ. Agreem. 2009, 9, 409-429. [CrossRef]

42. Ryan, G.W.; Bernard, R.H. Techniques to Identify Themes. Field Methods 2003, 15, 85-109. [CrossRef]

43. Fairclough, N. Discourse and Social Change; Polity Press: Cambridge, UK, 1993.

44. Kvale, S.; Brinkmann, S. The Qualitative Research Interview (Den Kvalitativa Forskningsintervjun); Studentlitteratur: Lund, Sweden, 2009.

45. Boréus, K.; Bergström, G. Analyzing Text and Discourse: Eight Approaches for the Social Sciences; Sage: Thousand Oaks, CA, USA, 2017.

46. Ryan, G.; Bernard, R. Techniques to identify themes. Field Methods 2003, 15, 85-109. [CrossRef]

47. Åsvoll, H. Abduction, deduction and induction: Can these concepts be used for an understanding of methodological processes in interpretative case studies? Int. J. Qual. Stud. Educ. 2014, 27, 289-307. [CrossRef]

48. Bowen, G. Grounded Theory and Sensitizing Concepts. Int. J. Qual. Methods 2006, 5, 12-23. [CrossRef]

49. Defining Key Concepts, Tools and Operational Responses, Peace and Conflict Tool; Sida: Stockholm, Sweden, 2017.

50. Government Offices of Sweden. Strategy for Sweden's Development Cooperation with Ethiopia 2016-2020; MFA: Stockholm, Sweden, 2016.

51. Government Offices of Sweden. Results Strategy for Sweden's Development Cooperation with Kenya 2016-2020; MFA: Stockholm, Sweden, 2016.

52. Government Offices of Sweden. Strategy for Sweden's Development Cooperation with Somalia 2018-2022; MFA: Stockholm, Sweden, 2018.

53. Government Offices of Sweden. Strategy for Sweden's Development Cooperation with Sudan 2018-2022; MFA: Stockholm, Sweden, 2018.

54. Government Offices of Sweden. Strategy for Sweden's Development Cooperation in Sub-Saharan Africa 2016-2021; MFA: Stockholm, Sweden, 2016.

55. Interview \#2, Sida HQ.

56. Interview \#5, Sida HQ.

57. Interview \#6, Sida HQ.

58. Interview \#7, Sida HQ.

59. Interview \#3, Sida HQ.

60. Interview \#10, Sida HQ.

61. Interview \#4, Sida HQ.

62. UN Office for the Coordination of Humanitarian Affairs. Humanitarian Development Nexus. The New Way of Working; International Council of Voluntary Agencies, 'Learning stream: Navigating the nexus. Topic 1: The "nexus" explained', Humanitarian Learning, briefing paper; UN Office for the Coordination of Humanitarian Affairs: New York, NY, USA, 2018.

63. The Swedish National Audit Office. Sida's Humanitarian Aid and Long-Term development Cooperation-Prerequisites for Collaboration' (Sidas Humanitära biståNd och låNgsiktiga Utvecklingssamarbete_Förutsättningar för Samverkan); The Swedish National Audit Office: Stockholm, Sweden, 2019.

64. Interview \#8, Sida HQ.

65. Interview \#9, Sida HQ.

66. Interview \#11, Embassy.

67. Interview \#14, Embassy.

68. Mavelli, L. Resilience beyond neoliberalism? Mystique of complexity, financial crises, and the reproduction of neoliberal life. Resilience 2019, 7, 224-239. [CrossRef]

69. Ruszczyk, H.A. Ambivalence towards discourse of disaster resilience. Disasters 2019, 43, 818-839. [CrossRef]

70. Smith, D.; Vivekananda, J. A Climate of Conflict. Sida International Alert; Sida: Stockholm, Sweden, 2008.

71. Sida. Environmental and Climate Change Indicators: Guidance at Country and Sector Level; SIDA61411en; Department for Policy Support, Sida: Stockholm, Sweden, 2010.

72. Schaar, J. The Relationship between Climate Change and Violent Conflict; Green tool box/peace and security tool box: Working paper; Sida: Stockholm, Sweden, 2017.

73. Bryld, E. Evaluation of Sida's Support to Peacebuilding in Conflict and Post-Conflict Contexts, Synthesis Report; Sida: Stockholm, Sweden, 2019.

74. Bjarnegård, E.; Uggla, F. Putting Priority into Practice: Sida's Implementation of its Plan for Gender Integration; EBA report 2018:07; EBA: Paris, France, 2018.

75. Åhrgren, L.; Cesar, E.; Öhlund-Wingqvist, G.; Ek, G.; Göthberg, M.; Stephansson, E.; Ekbom, A. Environment and Climate Change Integration in Sida's Development Cooperation-An Overview; Sida Studies in Evaluation; Sida: Stockholm, Sweden, 2019.

76. Organisation for Economic Co-operation and Development (OECD). OECD Development Co-operation Peer Reviews: Sweden 2019; OECD Publishing: Paris, France, 2019.

77. Interview \#13, Embassy. 
78. Persson, Å.; Klein, R.J.T. Mainstreaming adaptation to climate change in official development assistance: Building on environmental policy integration. In Climate Change and Foreign Policy: Case Studies from East to West; Harris, P., Ed.; Routledge: London, UK, 2009.

79. Guljarani, N.; Mills, L. Fit for Fragility? An Exploration of Risk Stakeholders and Systems Inside Sida; EBA report 2019:02; Expert Group for Aid Studies: Paris, France, 2019.

80. Interview \#12, Embassy.

81. Arndt, C.; Tarp, F. Aid, environment and climate change. Rev. Dev. Econ. 2017, 21, 285-303. [CrossRef]

82. Vink, M.; Schouten, G. Foreign-funded adaptation to climate change in Africa: Mirroring administrative traditions or traditions of administrative blueprinting? Rev. Policy Res. 2018, 35, 792-834. [CrossRef]

83. Janus, H.; Klingebiel, S.; Paulo, S. Beyond aid: A conceptual perspective on the transformation of development cooperation. J. Int. Dev. 2015, 27, 155-169. [CrossRef] 